(5) Similar triangles are equal in all respects-sides equal to sides, angles equal to angles, areas equal to areas. Similar triangles are to each other as their bases.

(6) Similar triangles are to one another in the duplicate or subduplicate ratio of their homologous sides. Their areas are as the square or square root of their bases according as it is in the duplicate or subduplicate ratio.

(7) Similar triangles are to one another as their bases. They are also to each other in the duplicate ratio of their homologous sides.

(8) Triangles are said to be similar when they have their corresponding sides equal and are equal in area. Similar triangles are to one another in the duplicate ratio of their homologous sides.

Each of these exhibits a pleasing variety and a liberal-minded, large-hearted toleration of conflicting views.

Such examples might be multiplied almost indefinitely, and they show clearly the impotence of the dictum " similar triangles are to one another in the duplicate ratio of their homologous sides " to convey any real knowledge to the mind of the ordinary learner. "Duplicate ratio" and "homologous" are mere sounds, to the latter of which violence is often done, inasmuch as I have frequently met with "homolicus" and "harmologous" sides.

Now, as regards the amount of time which is spent in the schools by young boys in acquiring the elementary facts and conceptions of geometry from Euclid's book, I know that very many months are occupied in attaining to the twelfth proposition of the first Book. I have before me, in fact, a fair-sized treatise written for the purpose of guiding boys along Euclid's exact path to this proposition.

There is absolutely nothing in the first twelve propositions that could not be taught far more effectively to a boy of ordinary intelligence in a few days, if only a rational style of teaching geometry were adopted; but if the exact language and pedantic professionalism of the school Euclids must be followed, to the weariness of the boy's mind and the quenching of his interest, it becomes a very long process indeed-ending, in the case of a large number, in utter failure.

Moreover, the current practice which insists on compelling boys to study geometry in an order and language characteristic of mediæval times, when no physical sciences existed, is a hindrance to the study of such sciences now, inasmuch as geometry is one of the foundations of all exact science; and it is obvious that if an intelligent knowledge of geometry is postponed, the physical sciences must be kept back also.

The plea that Euclid's book is unrivalled as an exposition of clear logical method and arrangement, and, as such, must be the foundation on which to build geometry, is vain-for the simple reason that it is not in England (where Euclid is worshipped), but in France and Germany (where Euclid is unknown as a text-book), that the great discoverers in geometry have been produced.

The late M. Paul Bert, Minister of Public Instruction in France, published a little book on the proper method of teaching geometry to beginners, in which he severely satirised the faults of the existing procedure; and, again, the late Rev. W. A. Willock (father of Dr. Sophie Bryant), in his "Elementary Geometry of the Right Line and Circle," has similar excellent remarks on this subject. "It is almost certain," says Dr. Willock, "that Euclid wrote his 'Elements' not for boys, but for grown-up, hard-headed thinking men."

Certain concessions have been made to the advocates of reform, led chiefly by Mr. Hayward-notably by the University of Oxford and the Civil Service Commissioners; and, in the existing state of affairs, it is not reasonable to expect more.

It will be clear from the foregoing that, in my opinion, a more rapid progress in the study of science generally would ensue from any system which would facilitate and accelerate the understanding of geometry by boys in the very elementary stage; and to this end I would suggest that the initiative should be taken by the Universities of Oxford and Cambridge. Our vast system of competitive examinations renders it necessary that a fixed source of authority on the order of deduction in geometry should exist. Such a source is Euclid at present; but a better one might, without serious difficulty, be drawn up by a University Committee, and its adoption by the schools and colleges throughout the country would follow as a matter of course. The chief difficulty is to avoid "fads"; but I learn, from conversation with a distinguished master in the largest of our public schools, that sympathy would not be wanting in an attempt to improve existing methods.

GEORGE M. MINCHIN.

The Cataloguing of Periodical Scientific Literature.

Some three years ago, I alluded, in a work on "The Theory of Bibliography" (pp. 8I-82), to the importance of learned societies undertaking to catalogue the literature they produce.

I pointed out that it was already necessary to supply tables of contents to each journal, bulletin, \&c., issued, and that a very slight amount of extra care would transform such tables of contents into technical Catalogues of articles, useful alike to the librarian and student-of which extra copies might be struck off at no expense. I referred to the noteworthy efforts of the $R$. Istituto Lombardo di Scienze e Lettere in registering the articles of foreign scientific journals in its Bulletin, and showed the advantages which would accrue if each society did its own work first.

I am happy to state that the society referred to has taken my remarks in the spirit in which they were written; and, in publishing vol. xxx. of its Rendiconti in 1897 , has issued accompanying sheets ("Titoli da ritagliare per le schede dei Cataloghi per Autori e per Oggetti") containing full titles (printed on one side only) of the articles appearing in the volume, under Author, Subject (and Place).

Melzi, Gilberto. - Sopra alcune rocce dell' isola di Ceylan. Rend. Ist. Lomb., serie 2, vol. xxx. p. 89. (Milano, 1897.)

Ceylan.- $\mathrm{C}_{\mathrm{x}}$. Melzi.-Sopra alcune rocce dell' isola di Ceylan.

Rend. Ist. Lomb., serie 2, vol. xxx. p. 89. (Milano, 1897.)

Geologia : Ceylan.-G. Melzi.-Sopra alcune rocce dell' isola di Ceylan.

Rend. Ist. Lomb., serie 2, vol. xxx. p. 89. (Milano, I897.)

(It would be advantageous to give the full pagination, e.g. pp. 89-102.-F.C.)

The advantages of such a course are obvious.

If each English learned society followed suit, and catalogued its own publications at the moment of issue, it would be only necessary to send the results to a central bureau (say the Royal Society), and the work of cataloguing our scientific periodical literature would be half-finished. There would still remain the task of editing-of sorting, classifying, and of occasional amplification or excision: but such work would be immensely lightened and facilitated if the preliminary actual cataloguing were already accomplished and in print.

This is the first and fundamental principle of co-operation in regard to the literature of the learned societies. Perhaps the Royal Society has already urged its application? If not, may I take this opportunity of drawing attention to the matter?

January $\mathbf{1 6 .}$ Frank CaMpBell (of the Library, British Museum).

\section{Plague in China}

IN the "Encyclopædia Britannica" (ninth edition, vol. xix. p. I68), Dr. J. F. Payne writes: "It is remarkable that of late years reports have come of the occurrence of Oriental plague in China. It has been observed in the province of Yunnan since $1871 \ldots$ it appears to be endemic, though there are rumours of its having been brought from Burmah, and become more noticeable after the suppression of rebellion in that province [1872]." However, the following passage I have lately found in Hung Liang-Kih's "Peh-Kiang-Shi-Hwa" (British Museum copy, 15,316, $a$, tom. iv., fol. $4, b$ ), bears witness to the much earlier occurrence of the pest in Yunnan, inasmuch as the author, who was born in 1736 , and died in I809, speaks of his contemporary dead thereby :- "Shi TauNan, the son of Shi Fan, now the Governor of Wang-Kiang, was notorious for his [poetic] gift, and was only thirty-six years old when he died. . . Then, in Cháu-Chau [in Yunnan] it happened that in daytime strange rats appeared in the houses, and lying down on the ground, perished with blood-spitting. There was not a man who escaped the instantareous death after being infected with the miasma. Tau-Nan composed thereon a poem, entitled "Death of Rats," the masterpiece of his ; and a few days after, he himself died from this 'queer rat epidemic." " KuMAGUSU MinaKata.

7 Effie Road, Walham Green, S.W., February II. 